\title{
Profile, Behavior and Condition Centers' Contribution towards Entrepreneurial Street Vendors: Case Study on the Central Street Vendors in Surabaya
}

\author{
Christina Menuk Sri Handayani ${ }^{1}$,Wara Pramesti $^{2}$, Suharyanto ${ }^{3}$ \\ University of PGRI Adi Buana Surabaya
}

\begin{abstract}
Street vendors are always a problem for cities, especially major cities which have a predicate metropolitan city such as Surabaya. Mayor of Surabaya always provide a place on the street vendors. In order to be more elaborated for street vendors and the beauty of the city is still kept so in 2008 the city government committed to the construction of Surabaya Central street vendors because it can create new jobs. Later in the development not all centers of street vendors went smoothly for that need to be examined how profile, behavior and condition centers' contribution towards sellers' entrepreneurship of street vendors. Sample taken in random is as much as 263 merchants. Data obtained by giving further questionnaires were analyzed by Multiple Linear Regression. The results showed that the profile (age, level of education, gender and educational level) and the behavior of traders do not contribute to the entrepreneurial spirit. Only condition centers contributed 0.87 towards to entrepreneurial street vendors in the central street vendors in Surabaya. From the conditions above, street vendors in the center needs to improve the entrepreneurial spirit in terms of innovation or differentiation of the commodities which are traded. Further, the Department of Cooperatives and Small Medium Enterprises need to reassess the requirements established the Center for Street Vendors in order to attract the interest of buyers which will ultimately increase the revenue of the street vendors.
\end{abstract}

Keywords: street vendors, entrepreneurial profile, entrepreneurial spirit, entrepreneurial behavior

\section{Introduction}

Most of the urban population in developing countries are living in poor conditions, many who work in the informal sector. It proves to be more than two-thirds of workers number in Indonesia are in the informal sector [1].Many found jobs that are not feasible (in ILO standard) particularly in the informal sector are popping up in the middle of the community. The informal sector currently plays a role in providing employment for the population with one of its easy to entry makes the probability of getting job in the informal sector are considerable. The informal sector is generally in the form of small-scale enterprises, capital, scope and limited development to work as street vendors. The presence of street vendors do not always need a formal education and higher skills and does not require a large capital. Street vendors re people with relatively little capital sought in the field of production and sales of goods (services) in order to meet the needs of specific groups within the community, the efforts carried out in the places that are considered strategic in the informal atmosphere of the surroundings.

Street vendors generally are self-employed, meaning the majority consist of one's labor. Capital owned relatively not too big, and is divided into fixed capital, in the form of equipment, and working capital. Capital rarely met from official financial institutions, usually derived from the illegal funds or from suppliers who supply merchandise. While the source of the funds that come from the savings on its own very little. This means that only a few of them can set aside the results of his efforts, due to their low levels of profit and how to money management, possibility to hold business expansion and capital investment is very small. Outline the difficulties faced by the Street Vendors ranged from government regulations regarding the arrangement of Street Vendors have yet to be built/constructive, lack of capital, lack of marketing facilities, and yet the existence of credit assistance [2].

Street Vendors is one important element in the empowerment of Small Medium Enterprises, this condition to the attention of the Minister of cooperatives and Small Medium Enterprises harif Hassan. With the rise of Small Medium Enterprises in East Java in General and Surabaya in particular. "it is a proof that Surabaya was one of the central of Small Medium Enterprises in Indonesia," He also reminds that even Street Vendors are not always condemned, but exact synergistic in beritanusa.com at Monday 26-5-2012. It is similar with the resident of the Republic of Indonesia on the one year anniversary of the movement's National Entrepreneurship and empowerment of Street Vendors, that he hoped to be able to run her business Street Vendors in accordance with the set and styled by local governments. Ikhwan Asrin, Deputy Marketing and Business Networking Ministry of cooperatives and Small Medium Enterprises[3]. States Street Vendors in the vision of the Agency is a tough businessman should be rewarded. "If Street Vendors directed and built as 
well as empowered, their impact on the regional and national economy so violent,"street vendors is the difficulty experienced by the economy's impact on society. State of the economy which is increasingly uncertain, the prices of basic necessities increasing family income that are likely not increase will result in disruption of the family economy.

The rise of the business in major acities successfully move people from the village to the city in order to switch the profession from the peasants to become street vendors. Street Vendors have always been a problem for cities that are developing especially large cities that already have a predicate, such as the metropolitan city of Surabaya.[4]. So traders are more elaborated and beautiful city staying awake since 2008, the Government of the city of Surabaya construction Center for Street Vendors.

Center for Street Vendors are able to create new jobs for 2400 people. In surabaya.tribunnews.com, Surabaya Metro Sunday, May 27, 2012, Up to the year 2014 there are 29 Center Street Vendors who were declared active with 844 traders.

The increase of street vendors is accompanied by increasing the Central treet Vendors, the Government stablished by the city of Surabaya are very interesting to review. The steps that need to be done is knowing the merchant profile is decentralized, the behaviour of traders, condition enters. Urther contributions will be sought between variables, variables which contribute most towards entrepreneurial treet vendors. The end result is used as an input in managing centers or set up a new relation in this regarding the Department of Cooperatives and Small Medium Enterprises Surabaya city.

\subsection{Street Vendors}

\section{Theoretical Frameworks}

Street vendors are small traders generally acts as a supplier of goods and services for the city' seconomy. The presence of street vendors can be found both In developing and developed countries. The term is derived from the five feet of pavement that used easuring the width of 5 feet or the equivalent of approximately 1.5 metres, so in this sense Street Vendors are selling merchants on a five foot, and usually take place or location in the crowd such as public sidewalks in front of the shops or commercial area, markets, schools and movie theaters[5].

Gives the sense of Street Vendors with hawker, defined as a group of people offering goods and services for sale on the public space, especially on the side of the road and the sidewalk [6]. Informal businesses in town, including a small business operator who sold food and goods or offer services involving economic and money market transaction.

This is referred to as the urban informal sectors or Urban Informal Sector. As a business unit, the business activities of informal Street Vendors because it does not have the legality of the effort. The relationship is informal partnership built which means do not use the written agreement between them [7]. he activity of street vendors can be categorized based on:

\subsubsection{Types of goods and services}

Category of activity of street vendors ased on the type of goods and services sold can be either : 1) food and beverage Grocery) 2) a little store 3) apparel/textiles 4) fruits and vegetables 5) Smoking and drugs 6) magazines, books an newspapers 7) children's toys 8) arts and crafts Toys 9) individual Services Each type of goods and services can be detailed further, e.g. grocery consists of household tools, children's toys, electronic goods, accessories and so on. Likewise the service individuals like Carpenter, locksmith, stam repair, hours, clamp the tyre and so on.

\subsubsection{Types of Space}

The activity of street vendors occupy the space consists of a public space and private space. The common room, which is kind of the Government-owned space as a spacedevoted to the interests of society at large. Like city parks, walkways, open spaces,fields and so on. Including facilities/means/in public spaces is a stop pedestrian bridges and so on. While the private sphere, i.e. the kind of space that is owned by an individual or a specific group, such as private land owned by the owners of the shops, offices and so on.

\subsubsection{The type of business and size of its spatial tools}

The activity of street vendors can be grouped based on the type of business and size of the spaces, namely:

\subsubsection{Wagons/stroller}

The activity of street vendors using pushcarts/stroller was divided into two kinds, namely carts/stroller wagon roof and stroller using the roof to protect themerchandise from the influence of heat, dust, rain and so on. 


\subsubsection{Pole}

The activity of street vendors use a fruit basket or two by way of bear. The form of thispole can be categorized in the form of an informal service activities is the circumference of a semi or settled, usually found on the kind of food and drink.

\subsubsection{Semi Permanent Stalls}

The activity of street vendors comprising some carts/pushchairs which have beenarranged in lined and fitted with long benches and desks. Part of the roof and it is covered with a protective fabric made from plastic tarps, or other fabric that does notpenetrate the water.

\subsubsection{Jongko or table}

The activity of street vendors who use jongko/table as a means of his tampa roof there are undercover to protect the influence from the outside. Based on the means ofeffort, then this is the informal sector services activity the service resides.

\subsubsection{Kiosk}

The activity of street vendors use a board that is set such it resembles a semi permanent booths. The buyer usually resides in it. By means of such business activity services, the informal sector is classified as a service activity reside.

\subsection{Center for street vendors in Surabaya}

Surabaya is one of the major cities in Indonesia. As a big city not be separated with the urbanization of society from village to town to get a better liveliho od. With noarmed with education and good skills, so a lot of people who fail to get jobs in the formal sector are finally looking for business opportunities in accordance with its ability. The shortcut does society like this is re-opening a potluck with became street vendors. Their existence increasingly irregular, especially in strategic places here they presume in city even the venue promises to be able to fulfill his life. Addressing the conditions above, the Government of the city of Surabaya always provide coaching and improving continuously to improve the quality both in terms of the institutional setup, place of business or capital as the embodiment of Perda No: 17/2003 about structuring and empowerment of Street Vendors. As a government agency, the Department of cooperatives and Small Medium Enterprises have carried out most of the Affairs of Government, namely the field of cooperatives and small and medium enterprises, the field of community empowerment, regional autonomy, public administration, financial administration, the devices area of the region, staffing andsupplies.

The duty stated in Perda No. 8 in 2008 about the details of the duties and functions of the Office of the city of Surabaya. Street vendors are part of the responsibilities of the Department of Cooperatives and Small Medium Enterprises Based on the development of Street Vendors in Surabaya are divided into two categories:

\subsubsection{Center for street vendors}

where street vendors in performing work/everyday trade occupies a location has been provided by the City Government in this Co-operative and Small Medium Enterprises Department

\subsubsection{Street vendors is a small-scale}

street vendors who daily in an attempt to occupy the site in accordance with the provisions and tents used as a place of companionship. In 2009, the Government of the city of Surabaya that Street Vendors do maintenance accommodated is officially in a place that is localized and is situated at a strategic point. Such as the Center for Street Vendors in the streets of Urip Sumoharjo. The area make Street Vendor are centralized with the concept of urban tourism and culinary tourism segment. The Center is expected to create an atmosphere to be more clean, more orderly, comfortable and do not interfere with traffic or road users [8].

The cooperatives and Small Medium Enterprises authorized to inventory and provide guidance to all the Street Vendors who are in the centers. Traders were given freedom of retribution and the extension of permission to sell nevertheless to guarding such centers tradesmen provide hygiene, maintain facilities as well as other common facilities provided by the Department of Cooperatives and Small Medium Enterprises. In addition, traders also get on-site coaching (Bimtek) periodically as a way of selling, health, nutrition, hygiene, and others. In the execution ofeveryday merchants under the coordination of the Chairman are selected based on each merchant agreement centers in charge of coordinating the traders in maintaining security, comfort in selling. Up to the year 2014 is already 29 Centers occupied approximately 1,110 traders, with the spread as in the table 1 . 
Table 1. Center for street vendors in Surabaya

\begin{tabular}{|l|l|l|l|l|l|}
\hline Number & Name & Booth & Number & Name & Booth \\
\hline 1 & Taman Bungkul & 50 & 16 & Sememi & 40 \\
\hline 2 & Urip Sumiharjo & 34 & 17 & Kandangan & 40 \\
\hline 3 & Dharmawangsa & 50 & 18 & Babat Jerawat & 40 \\
\hline 4 & Penjaringansari & 25 & 19 & Lidah Wetan & 40 \\
\hline 5 & Terminal Manukan & 42 & 20 & Lidah Kulon & 40 \\
\hline 6 & Ketabang & 35 & 21 & Sumber Rejo & 35 \\
\hline 7 & Sukomanunggal & 40 & 22 & Pondok Maritim & 35 \\
\hline 8 & Wiyung & 40 & 23 & Food Street(Unitomo) & 35 \\
\hline 9 & Putro Agung & 40 & 24 & Jambangan & 40 \\
\hline 10 & Indrapura & 42 & 25 & Sawah Pulo & 40 \\
\hline 11 & Taman Prestasi & 42 & 26 & Dukuh Menanggal & 40 \\
\hline 12 & Gayungan & 32 & 27 & RMI Kebon Bibit & 40 \\
\hline 13 & Deles Merr & 25 & 28 & Gunung anyar & 30 \\
\hline 14 & Pegirikan & 25 & 29 & Semolowaru & 25 \\
\hline 15 & Karah & 68 & Total & & 1110 \\
\hline
\end{tabular}

Source: Cooperative and Small Medium Enterprises Agency of the city of Surabaya

\subsection{Entrepreneurial spirit}

Entrepreneurship is the ability to create something new in the creative/ innovative and capable to take risks over the decision and carry it out as a result of his creation is best so that the expected added value can be achieved. An entrepreneur has the ability to think of something that hasn't been thought of by others (the principle of creative and innovative). In addition to the ability of the creative/innovative entrepreneur, also has the spirit that is indicated by: (1) the growth of action on his own volition and not because of any party; (2) progressive andresilient (3) initiative (4) control from inside, and (5) stability of the self [9]. While entrepreneursp is a creative and innovative ability in creating something new and different, which provided the basis and business tips or improvement of life. Entrepreneurial sense based on the opinion of Thomas W Zimmerer cited by Suryana (2002) is a process of applying creativity and innovation in solving problems and finding opportunities to improve the lives of business. Although someone has the entrepreneurial traits, but not necessarily he is successful in his efforts. Things that lead to a successful entrepreneur is (1) disciplines (2) High (3) a commitment to honest, (4) creative and innovative (5) realistic. [10]

[11] Define entrepreneurship as someone who found new innovations include: new products, new production methods, new markets and new organizational forms. The more demand for these new discoveries will ultimately creating prosperity and will bring benefits to the community. Self-employment or we call was a pioneer entrepreneur in new business or a manager who is trying to fix a change initiated by the organizational unit shape. Management Systems International mention personal entrepreneurial characteristics as follows: (1) looking for opportunities (2) ductility (3) responsibilities of the job (4) demands on the quality and efficiency of risk taking (5) risk taking (6) set the target (7) looking for information (8) systematic planning and control (9) persuasion and networking/connection (10) confident.[12] [13].

States that learning about entrepreneurshipvalues, capabilities and behavior of a person in a creative and innovating. Likewise, [13] states that entrepreneurship is a combination of creativity, innovation, and the truth, face the risks undertaken by way of hard work to establish and maintain a new venture. Creativity is thinking of something new, while innovation is the act of doing something new. In fact, entrepreneurship is a ephistimologic ability in creative thinking and behaving the innovative basis, resources, power, purpose, strategy, tips in the face of life's challenges.

\section{Research Methods}

This research was conducted to provide an explanation of donations between research variables. Variables in the research consists of a free variable (the variable $\mathrm{X}$ ) which consists of a profile (age, level of education, gender and marital status), the behavior of traders (the experience of selling old, selling in the centers, while selling every day,number of employees, the number of shoppers per day), condition centers (location selling, crowded shoppers, selling rules, solidarity between merchants, security, comfort, facilities, training, management associations) and variable (the variable Y) i.e.entrepreneurial street vendors (honesty, taking risks, confidence, hard work, passion and responsibility).Implementation of the research done on street vendors who trade in areas where street vendors in Surabaya.

Determination of samples according that representative sampling, depending on population.[14] If a homogeneous population, then the samples taken just $5 \%$ only, but in a heterogeneous population, the number of samples must be raised. Determination of the limit on the size of the random sampling formula used $1000<n=N /\left(1+E^{\wedge} 2\right)$. [14] Street vendorsin Central Surabaya amounted to 844 with the equations above, set the sample as much as 270 . 
The data obtained using the Likert scale questionnaire and assessment interval for each answer is 1 to 5. To find out whether a valid instrument done test against 30 respondents by using Correlation of Pearson (r), when the trial results at any granule $>r$ values of 0.3 and the grain was declared invalid. [15]. To test the reliability of the instrument that was made to use reliability coefficient (Alpha Cronbach). Whenthe alpha value of the research results $(\alpha)$ is above 0.6 means reliable research data. [16]

\section{Data Analysis}

Instrument given to respondent as much as 285 people, once done editing 263 qualifies for samples. Data analysis obtained by using a descriptive analysis to describe the variables examined or to describe the tendency of revealing perceptions that can contribute to the entrepreneurial spirit and then analyzed by Multiple Linear regression test. To obtain results that satisfy the requirements of Multiple Linear regression analysis, the analysis of the test done prior to assumption in advance.

\section{Results and Discussion}

Results of the research note that the street vendors who are in the Central City of Surabaya were Street Vendors at the age of 36 to 55 years as much as $69.20 \%$. Only $15.59 \%$ merchant with age above 55 years old which means traders are at a productive age. The majority of traders is then $(55.13 \%)$, and was married as many as $81.37 \%$. Research results are also known to Street Vendors is a graduate education high school or Vocational high school and as many as 130 people $(49.43 \%)$. However there is an educated Scholar as many as 27 people (10.27). This is similar to the results of research conducted by Christina (2013) that Street Vendors who are in the majority are centers at age 31-45 years old, male sex can be said that the main source of income is PKL's family, because men are the backbone of the family.

The results of research related to behavior that results obtained by merchant experience by selling an average of more than eight years as much as $49.05 \%$, which means traders before being in areas already as the street vendors who sell on the roadside or at the places where the place of selling as a cooperation. As many $44.87 \%$ of traders selling on average per day selling between 7-10 hours but there are selling for more than 10 hours with an average buyer per day between 30-40 persons (42,21percent). Employees or that helps one person still belongs to the family (child/husband/wife) as much as $64.26 \%$, only $4.94 \%$ of street vendors who had employees more than three people. This is confirmed by the results of basic research Alim Tualeka (2013) that the Street Vendors are not alone in running its businessthey already have an Assistant to keep the selling.

Merchants feel easy and affordable as much as 50.57\%. This shows that based on residence, owned most of the areas where they exist to sell (interview with the Chairman of the Center street vendors). The results shows that the location of the Centers crowded shoppers, sense of safe and comfortable selling in the Centre than on the side of the road, there is solidarity between friends, training of the cooperatives can add insight in selling and supported the presence of the Chairman of that trial ontraders.

The results of the study show that in terms of the honesty of the traders in selling does not reduce quality in terms of taste and amount, traders also dare to take risks and willing to accept the fact if there were no buyers and always responsible for selling in the centers keep coming. Research suggests that entrepreneurial soul traders in areas where very high which means there is an entrepreneurial spirit in the body of the scrimmage traders will further foster the motivation/passion to be the best selling presents. This condition will be mouth-watering markets when coupled with differentiation of selling in order to compete on an ongoing basis as it was conceived by Michael e. Porter. [8]. The above description of the results further analyzed by using Multiple Linear regression analysis, the results are as below.

Table 2. Results of The Analysis Of Variance Test Concurrent

\begin{tabular}{|l|l|l|l|l|l|}
\hline Source variation & df & Sum of Squares & Mean Square & F & Sig \\
\hline Regression & 6 & 5658,46 & 943,08 & 33,05 & 0,000 \\
\hline Error & 256 & 7304,42 & 28,53 & & \\
\hline Total & 262 & 12962,88 & & & \\
\hline
\end{tabular}

From table 2, retrieved the decision reject $\mathrm{H} 0$ because their significance value 0 is smaller than the specified alpha, which is 0.05 . This means that at least one of the lastage, education, gender, status, behavior, condition centers tradesmen did not have themeans to contribute to the entrepreneurial spirit.

Table 3. Test Results of Partial Regression Model Parameters

\begin{tabular}{|l|l|l|l|l|l|}
\hline No & Predictor & Coefficients & Coefficients Standart Error & $\mathbf{T}_{\text {accounted }}$ & Sig. \\
\hline 1 & Constants & 31,358 & 3,961 & 7,92 & 0 \\
\hline 2 & Age & 0,2213 & 0,3576 & $-0,62$ & 0,537 \\
\hline 3 & The Last education & 0,2729 & 0,3872 & 0,70 & 0,482 \\
\hline 4 & Sex & 0,0907 & 0,6828 & 0,13 & 0,894 \\
\hline
\end{tabular}


Profile, Behavior and Condition Centers' Contribution Towards Entrepreneurial Street Vendors: ..

\begin{tabular}{|l|l|l|l|l|l|}
\hline 5 & marital Status & $-0,5576$ & 0,4948 & $-1,13$ & 0,261 \\
\hline 6 & Trader Behavior & 0,1422 & 0,1041 & 1,37 & 0,173 \\
\hline 7 & Centers Condition & 0,87439 & 0,06562 & 13,33 & 0 \\
\hline
\end{tabular}

Table 3, on a partial basis, regression test first the value of significance is 0 , meaning all $\mathrm{H}_{0}$ defends variant response can be explained by the predictor.

Both the value of their significance 0.537 is failing to reject $\mathrm{H}_{0}$ does not contribute to the meaning of age on the entrepreneurial spirit. On the third, partial regression test value ofsignificance is 0.482 then failed to reject H0. It means education last did notcontribute to the entrepreneurial spirit on which means. On the fourth, partialregression test value significance 0.894 is failing to reject Ho, meaning that gender did not have a meaningful contribution on the entrepreneurial spirit. To test the fifth partial about the behavio of traders earn significant value $0.261>0.05$ failed to reject Ho, meaning the behavior of traders have no meaningful contribution on the entrepreneurial spirit.

The sixth test obtained significant value 0.173 failed to reject the test condition the central Ho .obtaining significant value from 0 meaning conditions Ho defends Center save meaningful contributions on the entrepreneurial spirit.

\section{Limitation of the study}

Since the variables of profile, behavior and center condition which contribute to the spirit of entrepreneurship of street vendors, it enables further research to be conducted to other areas of interests.

\section{Conclusion}

Based on the results of analysis by using multiple linear regression, then it can be concluded that: Variable profile consisting of age, education, sex and the last status of marital status has no meaningful contribution on soul entrepreneurial street vendors who are in areas where Street Vendors in Surabaya. The trader has no meaningful contribution on soul entrepreneurial street vendors who are in areas where Street Vendors in Surabaya, therefore requires a suitable partnership for cooperation with third parties in connection with the addition of science, funding source or sponsor. Conditions are variable Centers contribute to the entrepreneurial spirit on which means street vendors who are inareas where Street Vendors in Surabaya and Department of cooperatives and Small Medium Enterprises need to reassess the requirements established the Center for Street Vendors in order to attract the interest of buyers which will ultimately increase revenue trades.

\section{Acknowledgements}

The authors would like to give a big thank you, first to the Kemenristek HIGHER EDUCATION as the founder of the grants in this research. Both addressed to the Rector of the University PGRI Adibuana Surabaya, Dean of the Faculty and staff of the Economics University PGRI Adibuana Surabaya which has provided help and support so that the study can be completed. Gratitude of thanks is also given to the merchants who have helped provide data so that this research can be realized. Thanks also to SMALL MEDIUM ENTERPRISES and Cooperatives service of Surabaya, as well as all those who delighted in helping either directly or indirectly in the completion of this study. Hopefully this research can be useful for those who have problems as jarring advice in taking policy.

\section{References}

[1]. Manning,Chris dan Effendi ,Tadjuddin Noer dan Tukiran,2001, Struktur Pekerjaan, Sektor Informal dan Kemiskinan di Kota, Cetakan Kelima, Yogyakarta: PPK UGM. p : 230

[2]. Auliya Insani Yunus, 2011, Potret Kehidupan Social Ekonomi Pedagang Kaki Lima di Kota Makasar ( Kasus penjual Pisang EPE di Pantai Losari). p: 40-42 http://Respository-unhas.ac.id accessed on June 19, 2013

[3]. www.depkop.go.id, Memanusiakan Para Pedagang Kaki Lima (ginting-munthebisnis.co.id) Accessed 2 March 2013

[4]. Herwanto,2012, Resistensi pedagang kaki Lima dalam Menghadapi Penataan yang dilakukan oleh pemerintah Kota Surabaya, (www.dfisip.web.unair.ac.id) downloaded on 9 March 2013

[5]. Widodo,Ahmadi. 2000, Faktor-Faktor Yang Mempengaruhi Pemilihan Lokasi Usaha PKL, Studi Kasus Kota Semarang. Tesis tidak diterbitkan. Program Pascasarjana, Magister Teknik Pembangunan Kota, Universitas Diponegoro, Semarang. (www.eprints.undip.ac.id) Accessed 25 February 2013)

[6]. Retno Widjajanti,2009, Karakteristik Pedagang Kaki Lima pada Kawasan Komersial di Pusat Kota ( Studi kasus Simpang Lima Semarang ) TEKNIK. Vol 30 No.3 tahun 2009 ISSN 0852-1697 p : 162-170

[7]. Nurul Widyaningrum, 2009, “Kota Dan Pedagang Kaki Lima”, Jurnal Analisis Sosial Vol 14 No.1 Mei 2009, Yayasan Akatiga, Bandung. p: 1-18

[8]. Wispandono, Moch, 2011, Upaya Mengurangi Penggangguran Melalui Peningkatan Wisata Kuliner ( Studi Pada Pedagang Kaki Lima di Surabaya, Beranda, Vol 1 No 1 Journal.unipdu Accessed on 2 March 2013

[9]. Kemendiknas, 2010, Dirjen Peningkatan Mutu Pendidikan dan Tenaga Kependidikan Materi Pelatihan Penguatan Kemampuan Kepala Sekolah (Kewitausahaan Kepala Sekolah ). p : $6-7$

[10]. Suryana. 2002. Kewirausahaan: Proses Menuju Sukses, Jakarta : Salemba Empat Patria. p: 18

[11]. Kim Piew Lai, Robert Jeyukumar Nathan, Khong Sin Tan and Boon Bun Chan, 2010, Effect Of Innovation to the success of Female Entrepreneurs, Journal of Innovation Management in Small and Medium Enterprises, Vol 2010(2010). p : 1- 14 
[12]. Buchori Alma, 2004, Kewirausahaan, Bandung, Alfabeta, p. 95

[13]. Ernani Hadiyati, 2009, Kajian Pendekatan Pemasaran Kewirausahaan dan Kinerja Penjualan Usaha Kecil , Jurnal Manajemen dan Kewirausahaan, Vol 11 No. 2 September 2009 p:183-192

[14]. Arikunto Suharsimi, 2010. Prosedur Penelitian Suatu Pendekatan Praktis, Edisi V Revisi, PT. Rineka Cipta, Jakarta . p : 179

[15]. Ghozali, 2005, Analisis Multivariate dengan Model SPSS, Universitas Diponegoro, Semarang. p: 105

[16]. Sugiyono, 2005. Metode Penelitian Kuantitatif, Bandung,Alfabeta. p: 63 